\title{
AUTOMATIC PAPER POT TRANSPLANTING MACHINE
}

\author{
JIGNESH PATEL ${ }^{1}$, MEET ADESARA ${ }^{2}$, SHALIN GUPTA ${ }^{3}$, DHRUVIN MISTRY ${ }^{4}$ \& JUGAL PATEL ${ }^{5}$ \\ ${ }^{I}$ Assistant professor, Department of Mechanical Engineering, Indus Institute of Technology, Ahmedabad, Gujarat, India \\ ${ }^{2,3,4,5}$ Students, Department of Mechanical Engineering, Indus Institute of Technology, Ahmedabad, Gujarat, India
}

\begin{abstract}
The Automatic Paper Pot Transplanting Machineis distinctive equipment in the field of agriculture and mechanical. It uses the paper chain pots for transplanting the crops or seeds. A single set of paper chain pot contains 264 paper pots; all can be planted in less than a minute. The paper pots in series go through the narrow opening in the front side of the transplanter. The leading paper pot in the beginning of the chain needs to be pulled and staked to hold inside the ground. The Transplanter is then pulled in the backward direction and hence all the seeds or crops along with the paper pot get transplanted inside the farming land. . The adjustable plough underneath digs the soil with desired depth. The reaper in the front helps in cutting the crops when the transplanter is moved in forward direction. The transplanter being remotely operated proves to be efficient farming equipment. All these functions can be executed without any bending, kneeling or any other sort of human intervention. This proves to be much precise plantation process with less human effort possible.

KEYWORDS: Paper Chain Pot, Transplanter, Track Wheel \& Reaping
\end{abstract}

Received: May 13, 2020; Accepted: Jun 03, 2020; Published: Aug 03, 2020; Paper Id.: IJMPERDJUN2020576

\section{INTRODUCTION}

Vegetable and plantation holds a great importance in all living creatures especially humans consuming and surviving with the help of these plantations. Along with which the process of growing these vegetables also becomes much important. In the ancient times, people manually sorted out the seeds and then plant them manually inside the land by digging the soil. This was the basic initial method of planting. As the time grew, people invented new creative ideas of improving the plantation process. They came up with different sort of machines and mechanisms which made this process much easier with less effort required compared to previous methods. Tractors equipped with planting mechanism, vertical sowing machine etc. are few examples of it. But all these advancements had some kind of drawbacks and imitations due to which the human problems persisted. The amount of crops planted being less, improper utilization of farming land, high cost of equipments and maintenance, labour and damage to the crops were the prime problems faced by the farmers. Especially in India, the farmers lack awareness in latest plantation techniques and also face financial crisis. Hence, keeping in mind all these factors, a technique was developed - Paper Pot Transplanting and the machine using this technique is Paper Pot Transplanter. The Transplanter is a simple construction made of mild steel which has a tray holder on which the paper chain pots are placed, a handle on the rear side with the help of which the transplanter can be pulled by the wheels and it has a narrow opening on the front side from which each paper pot from the paper chain will pass through it and get transplanted inside the soil when the transplanter is pulled backward. The transplanter works much efficiently and can plant 264 paper pots each having plants or seeds in less than a minute. The operation of the transplanter is very simple as the farmer just needs to load the seedling tray and then pull the transplanter backwards. All the process without bending or kneeling, just standing and pulling the transplanter backwards that's it. This transplanter also faced some problems like prerequisite digging 
of soil, depth of plantation, human effort in pulling the transplanter, transplanter getting stuck due to uneven farming land and putting back the dug soil. Hence by developing the transplanter further, we introduced an Automatic Paper Pot Transplanter. The transplanter is equipped with electric motor for pulling it backwards also with the help of remote control which reduces the human effort to the lowest possible. Adjustable plough is provided underneath the tray holder for digging the soil at a desired depth along the ongoing transplantation process and a $\mathrm{V}$ shaped ankle in the front which puts back the dug soil after plantation. The adjustable Reaper machine is also attached to the front side of the transplanter which can be used for cutting the crops when the transplanter is moved forward and when the planting process is not to be done.

\section{WORKING PRINCIPLE}

A paper pot transplanter is a specialized machine used to transplant paper pot seedlings in the field. A common paper pot transplanter requires a seedling tray like a shed roof on which mat type paper pot nursery is set. The paper chain pots are available in sizes of 2", 4" and 6" spacing between two successive crops. The paper chain is loaded on the tray and placed o the tray space provided on the transplanter. The first paper pot from the chain is then manually picked and placed inside the soil that hasalready been dug for it. The transplanter with the help of remote control is then operated in the backward direction powered by DC geared motors. The adjustable plough underneath the transplanter helps in digging the soil throughout the operation. The depth of plantation can be set initially by adjusting the plough to the desired depth. As a result, the paper pots will set inside the soil as the transplanter moves backward. One by one sequentially the crops will get planted and the soil will also get dug along with it. The paper being biodegradable doesn't harm the soil or the crop. It increases the approximate area that a person can plant from 700 to $10,000 \mathrm{~m}^{2} /$ day. The human intervention at each and every step of the transplanting process is eliminated, providing an accurate crop plantation. Also the transplanter can be operated within a particular range, away from the transplanter which helps in maintaining the crop and soil quality. The reaper machine is also attached in the rear end of the transplanter. The reaper being adjustable, it sits idle when the transplantation process is being done and doesn't interfere it. But when the necessity arises of cutting the crops after harvesting, the transplanter can be moved in forward direction with the reaper turned on. The reaper will cut the crops. Hence variable operations can be performed with the help of this automatic transplanter.
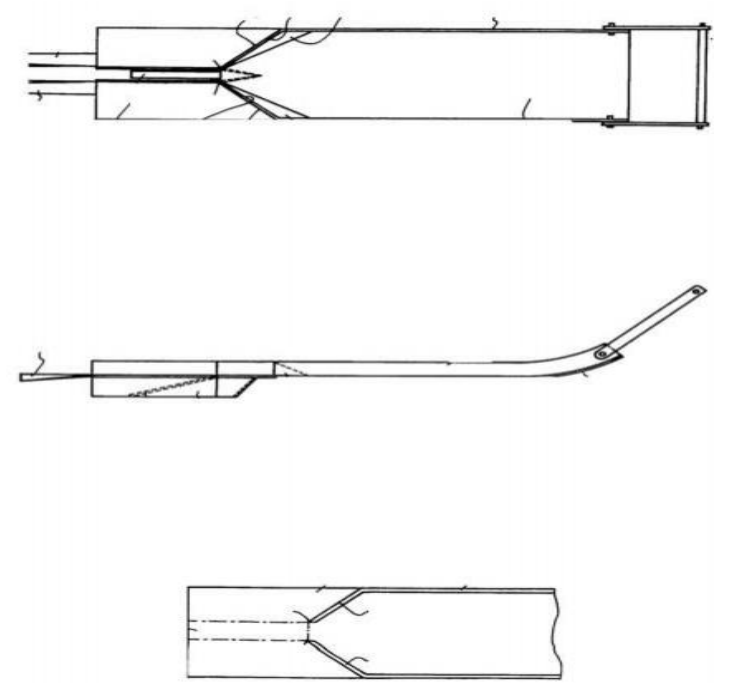

Figure 1: Conceptual Design.

\section{LIST OF COMPONENTS}


- FRAME

- SEEDING PLATE

- PAPER CHAIN POTS

- $\quad$ DC MOTOR

- BATTERY

- WHEELS

- $\quad$ NUT BOLT

- REAPER MACHINE

- REMOTE CONTROLLER

- PLOUGH

\section{DIMENSIONS OF COMPONENTS}

Table 1

\begin{tabular}{|l|l|}
\hline Tray & 600mm*300mm*30mm \\
\hline Handle & $\begin{array}{l}\text { Length: } 1250 \mathrm{~mm} \\
\text { Pipe diameter: } 1 \mathrm{~mm}\end{array}$ \\
\hline Wheel & $\begin{array}{l}\text { Diameter: } 110 \mathrm{~mm} \\
\text { Thickness: } 54 \mathrm{~mm}\end{array}$ \\
\hline
\end{tabular}

\section{DESIGN OF MODEL}

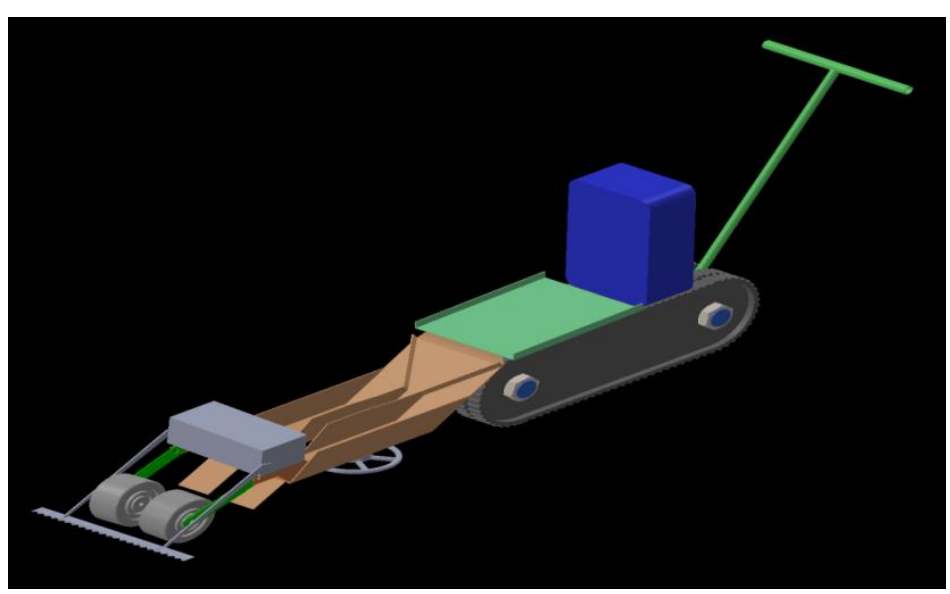

Figure 2: 3D Model Solid Works. 


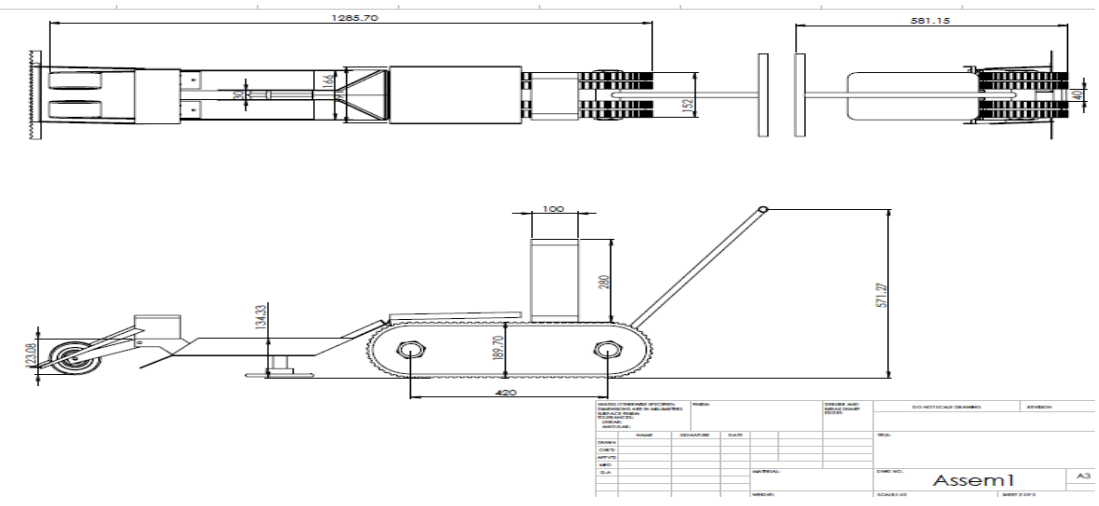

Figure 3: AutoCAD Assembly.

\section{WORKING}

Initially the paper pots are made with desired spacing between each pots and the chain of these paper pots is arranged on a tray.Soil along with the seeds is settled in each paper pots with the help of spreader.The tray is then placed to the allocation on the transplanter machine.The first paper pot from the chain is then pulled manually and placed inside the soil at the required depth of plant. The soil needs to be dug to some length for setting the first paper pot.The transplanter machine will then be operated and the paper pots from the chain will be transplanted in the land as the machine advances itself in a direction with the help of the automation unit attached with the transplanter machine.The digging hook underneath the machine will keep the soil digging for the transplantation. The $\mathrm{V}$ shaped angle on the front will put the dug soil back inside the land for completing the transplanting process. The Reaper machine can be operated for cutting the crops by moving the transplanter in the forward direction. The harvested crops can be cut and collected by the help of this reaper.

\section{COMPARISON WITH EXISTING TECHNOLOGY}

There are different versions of transplanters available in the current market with various features and equipped with multiple functioning technologies. The Automatic Paper Pot Transplanter is much varied relative to the transplantation process as compared to other transplanters.

The transplanter coupled with diesel engine requires more fuel and also increases the overall weight of the machine. Hence it reduces the efficiency. Also mechanism for fuel and power transmission increases the cost of the machine. Replacing the engine with a simple DC geared electric motor eliminates all these factors and makes the transplanter more efficient, less costly, simple and easy to operate and reliable.

The transplanters with plant picking and placing function also fail to work precisely as the plants or the crops tend to get separate or get damaged while in operation. The Automatic Paper Pot Transplanter requires paper chain pots with fixed 2', 4" and 6" spacing between consecutive plants and as they are attached with the help of biodegradable paper, the chances of uneven spacing and damage is very less as compared to the conventional methods. With the help of these paper chain pots, more plants can be transplanted quickly, in much less time with decreased probability of plant getting damaged. Also the plants are evenly and precisely spaced between each other.

The current version of the paper pot transplanter needs to be placed and pulled manually that ultimately increases the human effort. The Automatic Paper Pot Transplanter is equipped with remote control technology with the help of which the transplanter can be operated with the help of a remote controller within a particular range of distance. This also maintains the constant pulling speed of the transplanter as a result of which the risk of damage to the plants is reduced to a great extent. 
The human intervention in the transplantation process also becomes negligible, resulting to precise transplantation output.

The soil needed to be dug before starting the transplantation process in the conventional transplanter. The Automatic Paper Pot Transplanter is equipped with adjustable plough beneath the machine. The plough can be adjusted according to the required depth of plant. When the transplanter is being pulled, the plough will dig the soil and the plants will also get transplanted both at the same time. This eliminates the digging of soil manually before starting the process.

The Automatic Paper Pot Transplanter is also equipped with adjustable reaper machine on the rear end which can be activated for cutting the crops after harvesting. While transplantation process, the reaper is adjusted up to a certain height and remains idle. When the transplanter is moved in forward direction with activated reaper after adjusting its height, it will cut the crops. This function makes it much easier for the operator to collect the crops after harvesting and move them off.

As compared to other versions, this Automatic Paper Pot Transplanter will prove to be the most efficient transplanter till date, furnished with multiple functions at the ease of the operator.

\section{CAlCulation}

Dimensions of tray:- Length : $600 \mathrm{~mm}$, Breadth : $300 \mathrm{~mm}$, Height : $30 \mathrm{~mm}$, Area : 180000 sq. mm, Volume : $5400000 \mathrm{~mm}$ cube

- Dimensions of handle:- Length : $1250 \mathrm{~mm}$, Pipe used of 1 inch diameter

- Dimensions of wheel:- Diameter : $110 \mathrm{~mm}$, Thickness : $54 \mathrm{~mm}$

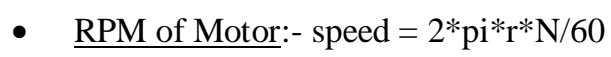

- $\quad 0.417 \mathrm{~m} / \mathrm{s}=2 * 3.14 * 0.055 * \mathrm{~N} / 60$

- $\quad \mathrm{N}=72.26 \mathrm{RPM}$

- $\quad$ Power of primary motor:- $\mathrm{P}=$ mass * gravitational force * linear speed

- $\quad=30 \mathrm{~kg} * 9.81 \mathrm{~m} / \mathrm{s} \mathrm{sq} . * 0.417 \mathrm{~m} / \mathrm{s}$

- $=122$ watt

So the $12 \mathrm{~V}$ DC geared motor of $10 \mathrm{Amp}$ current will be used for pulling the machine.

\section{CONCLUSIONS}

The paper pot transplanting machine will work satisfactorily. But, the improvements can be done before introducing to the farmers. The machine is driven by remote control but engine can be coupled to increase the performances. Machine can be developed to transplant the several rows simultaneously. Weight of the machine should be reduced by using light weight, strong and anticorrosive materials.The Reaper attachment can be upgraded with binder mechanism. The human effort and human intervention in the plantation process with the help of this automatic paper pot transplanting machine has been reduced to the maximum possible extent. It will prove to be much efficient and cost saving plantation method in the upcoming future.

\section{REFERENCES}

1. Mr.Akshay S kadlag, Mr.Prajwal S Tajane, Mr.Sagar S Pawase, Mr.Sarjerao H Shinde

2. Prof. Prashant B Wakchaure, “Automatic Planting Farm Equipment”, IJARIIE-ISSN (O)-2395-4396, Vol-5 Issue-2 2019. 
3. Dharmaraj M, Mounesh K M, Poovarasan R, Rahul R, "Design And Fabrication of Paper Pot Transplanter", International Journal of Scientific \& Technology Research Volume 9, Issue 01, January 2020.

4. Negalur, R. B., A. S. Halepyati, and M. Ananthachar. "Influence of land preparation methods and planting geometry on yield and engineering parameters of machine transplanted rice (Oryza sativa L.)." International Journal of Agricultural Science and Research (IJASR) 5.5 (2015): 201-207.

5. Abhijit Khadatkar, S. M. Mathur and B. B. Gaikwad, "Automation in transplanting: a smart way of vegetable cultivation", Current Science, VOL. 115, NO. 10, 25 NOVEMBER 2018.

6. JKonosuke TSUGA, “Development of Fully Automatic Vegetable Transplanter”, J RQ 34, 21 - 28 (2000)

7. Negalur, R. B., and A. S. Halepyati. "Different weed management practices in machine transplanted rice (Oryza sativa L.)." International Journal of Agricultural Science and Research (IJASR) 5.5 (2015): 183-189.

8. www.wikipedia.org/wiki/Paper pot_transplanter

9. www.knowledgebank.irri.org/epaper potproduction/II.5_Nursery_systems.htm

10. Rani, Hafnidar A. "Development priority of Road Infrastructure the Aceh post tsunami in Simeulue District." International Journal of Civil Engineering 6.3 (2017): 9-17.

11. https://www.johnnyseeds.com/tools-supplies/transplanters/paperpot-transplanter-7601.html

12. https://smallfarms.cornell.edu/2014/07/paper-pot/

13. Vivek, P., and V. Duraisamy."Study of Growth Parameters and Germination on Tomato Seedlings with Different Growth Media." International Journal of Agricultural Science and Research 7.3 (2017): 461-470. 